\title{
The New Generation of Auditors Meeting Praxis: Dual Learnings Role in Audit Students Professional Development
}

Lena Agevall, Pernilla Broberg and Timurs Umans

The self-archived postprint version of this journal article is available at Linköping University Institutional Repository (DiVA):

http://urn.kb.se/resolve?urn=urn:nbn:se:liu:diva-145805

N.B.: When citing this work, cite the original publication.

This is an electronic version of an article published in:

Agevall, L., Broberg, P., Umans, T., (2018), The New Generation of Auditors Meeting Praxis: Dual Learnings Role in Audit Students Professional Development, Scandinavian Journal of Educational Research, 62(2), 307-324. https://doi.org/10.1080/00313831.2016.1258663

Original publication available at:

https://doi.org/10.1080/00313831.2016.1258663

Copyright: Taylor \& Francis (Routledge) (SSH Titles)

http://www.routledge.com/ 


\section{The New Generation of Auditors Meeting Praxis}

Lena Agevall $^{\mathrm{a}}$

Pernilla Broberg ${ }^{\mathrm{b}}$

Timurs Umans ${ }^{\mathrm{c} *}$

${ }^{\text {a }}$ Linnaeus/Kristianstad Universities

${ }^{\mathrm{b}}$ Kristianstad/Linköping Universities

${ }^{\mathrm{c}}$ Kristianstad/Linnaeus Universities

*Corresponding Author

Tel: + 46442031377

Mob: + 46709403007

E-mail: Timurs.Umans@hkr.se

This study is included in a larger project titled 'The new generation of professionals meeting management by documents: Possibilities for double-edged learning' and supported by the 


\begin{abstract}
This paper explores whether and in what way "dual learning" can develop understanding of the relationship between structure/judgement and explores audit student's perceptions of the audit profession. Work Integrated Learning (WIL) module, serving as a tool of enabling dual learning, represents the context for this exploration. The study is based on a focus group and individual interviews conducted with students performing their WIL. Our data and its analysis indicates that when in a WIL context, students develop awareness of the use of standards and checklists on the one hand and the importance of discretional judgement on the other. Based on these results, we theorise as to how dual learning manifests itself in students' experiences and understanding of the relationship between structure and judgement.
\end{abstract}

\title{
Keywords:
}

Dual-learning, auditing education, work-integrated learning, professional education 


\section{Introduction}

Researchers in Sweden and other countries have been observing increasing pressure on professionals to perform their work according to regulations and standards. Manuals, checklists and pointed guidelines are just a few examples of documents that are used to control the work of the professionals and, as a result, push them to devote an increasing amount of time to administration (e.g. Agevall \& Jonnergård, 2007, 2012; Baldvinsdottir \& Johansson, 2006; Brunson \& Jacobsson, 1998; Power, 1997; Sahlin-Andersson, 2006;). This trend can be discussed in terms of "striving for transparency" (Levay \& Waks, 2009) or “management by documents" (Agevall \& Jonnergård, 2007); the latter includes both control through documents such as checklists and manuals and through requirements for documentation. As in other professions, audit professionals have experienced an increase in management by documents (Baldvinsdottir \& Johansson, 2006).

Auditing research distinguishes between two approaches to auditing: structure and judgement. Structure emphasises predetermined and systematic audit work based on guidelines, manuals, and computer support among others, as well as extensive documentation requirements. It represents the concept "management by documents"; Judgement emphasises auditors' knowledge, experience, and ability to distinguish what is important and upon this judgement to consider various options and make decisions (e.g. Knechel, 2007; Kosmala, 2005; MacLullich, 2001; Power, 2003; Smith Fiedler, Brown, \& Kestel, 2001; Van der Veer, 2006; Öhman, 2006; Öhman, Häckner, Jansson \& Tschudi, 2006).

Thus, auditing is an activity where the complex relationship between structure and judgement is central and important, especially in light of the debate as to which of those two approaches leads to a high audit quality (Broberg, 2013; Öhman, 2006). Yet, students fresh out of university usually lack experience in handling the relationship between structure and 
judgement. This implies that at the same time the new generation of auditors learn to use firms' institutionalised auditing procedures and use of standards, they have to learn to recognise the importance of using critical, free, and independent professional judgement. In order to conceptualise this aspect of students' entry into the professional world in this study, we have borrowed the concept of "dual learning" frii from Aili and Nilsson (2015) to represent the notion of simultaneously learning the auditing standards and audit firm procedures while maintaining independent in thought and action.

Often when first encountering with auditing practice, students are faced with changing from one learning context/arena - the university - to another - the workplace (Smeby, 2008). In one university programme though, students are crossing this boundary within the university setting through an educational model called work-integrated learning (WIL). The introduction to WIL and active involvement in this educational model, allows students to gain an understanding of the clash between structure and judgement as well of as the gap between theory and practice. Thereby WIL is used as a sort of "tool" to provide opportunities that enables dual learning.

We have reasoned that by concentrating on university students, who are the new generation about to enter the auditing profession, one can capture perceptions of the relationship between structure and judgement in a formative stage of their professional development. This would happened because the individuals would not have started working within and according to an audit firm system nor been subject to socialisation processes within the audit firm (cf. Broberg, 2013). Thus, the choice of the empirical object for this study not only provided us with an opportunity to explore dual learning but also to understand the as yet un-indoctrinated students' views on the audit profession. With this in mind, the aims of this paper are to explore whether and in what way dual learning can develop audit students' understanding of 
the relationship between structure and judgement and to explore students' perceptions of the audit profession.

\section{Literature review}

\section{Structure vs. judgement within the audit profession}

Auditing is a highly regulated profession (Öhman, 2006), and yet the work is based on the auditor's professional judgement (Eklöv, 2001). Rules can be formulated within a continuum from closed (i.e. precise) control to open (i.e. imprecise) control. The closed rules are contextfree and reduce all room for judgement and for adjusting to a specific situation or case. The open rules allow space for judgement, for the possibility of adjusting to a specific situation or case (Agevall, 1994; see also e.g. Mennicken, 2005, 2008).

Professions and professional work are often described as including uncertainty, complexity, and the need to exercise judgement (cf. Brante, 1988; Freidson, 2001). Accordingly, applying judgement is often seen as a crucial part of auditing (Eklöv, 2001). When auditors do their fieldwork (e.g. assess risks, set materiality limits, evaluate and test internal controls, identify strengths and weaknesses), they must (or at least should) adhere to the International Standards on Auditing (ISA), which require auditors to use professional judgement. It could be argued that professionals and professional products cannot be standardised and that there is a need "to exercise discretion and judgement from case to case" (Freidson, 1994:164). However, it has been argued that individual actors are shaped and influenced by factors inside as well as outside the organisations in which they are employed (Umans, Broberg, Schmidt, Nilsson \& Olsson, 2016). When it comes to auditors, the reality is that such factors include standardisation and regulation of professional conduct. These factors, including, for example, accounting and auditing standards, have become more prescriptive and detailed (FRC, 2006; Larson, 2007) and constitute auditors' official knowledge (Power, 1997). This more 
prescriptive approach has gained ground due to economic, regulatory, and political pressures (Bowrin, 1998; Humphrey \& Moizer, 1990; Power, 2003) such as those that followed the "business scandals" of the 2000s (e. g. Enron and WorldCom). It could be claimed that structure has also been developed and used within audit firms to gain legitimacy and control (Humphrey \& Moizer, 1990; Power, 2003) and by audit teams and individual auditors "to produce comfort” (cf. Broberg, 2013; Carrington and Catasús, 2007; Pentland, 1993).

Auditors seek to produce comfort (that they are carrying out sufficiently high quality audits) for themselves, their colleagues, and their employer (Broberg, 2013). They do it through rituals and acts and the significance of the signing auditor as the decision maker; in addition researchers have emphasised the role of emotional features within auditors' work (Broberg, 2013; Carrington \& Catasús, 2007; Pentland, 1993). Thus, the "uncertainties" that result from interpretations, assessments, and estimations mean that following "gut feel" (Broberg, 2013; Humphrey \& Moizer, 1990; Pentland, 1993) and producing comfort are central parts of audit work. This is partly because ISAs, even though pervasive, serve neither as unambiguous points of reference nor as ready-made tools. Hence, auditors cannot merely read the ISAs to determine what to do or how to do it. In Power's words:

So audit documentation is only partly descriptive: "the audit working papers 'do not tell the real story' of why decisions are made, and [processes of] ... selecting, or excluding, information from any explanations so as to create a desired portrayal of what happened (Gibbins, 1984:117)". The process of writing up makes the audit process conform, more or less well, to its institutionalized knowledge base (1997:37).

In practice, this has also involved audit firms developing their own interpretations of the standards, which together with their audit methodology are built into their firm manual (cf. Broberg, 2013). By using such manuals, auditors produce comfort. However, there are also signs that such a comfort implies less professional responsibility and that one motive for 
following the manual functions is to avoid the risk of being blamed. Carrington and Catasús (2007:44) argue that:

[f]ollowing the manual is the safest way to achieve relief from discomfort. First, since the manual relies heavily on structural knowledge (embedded in the manual), it relieves the senior from expanding their responsibilities of judgments. Second, following the manual also provides another aspect of relief from discomforts, namely, the risk of getting blamed.

Determining the roles of structure and judgement is a challenge. For example, it has been claimed that "[a]uditing is judgemental in its nature, and judgements are made in tacit and intuitive processes" and that "[s]uch processes are resistant to systematisation and are difficult to transmit formally" (Eklöv, 2001:62). At the same time, "the strict guidelines in the new international auditing standards, ISAs, can be seen as 'more structure and less judgement' " (Öhman et al., 2006:93). Auditors are expected to perform more qualitative assessment (Kosmala MacLullich, 2003:792) at the same time as there is a trend towards use of more regulation, principles, rules, and guidelines (e.g. FRC, 2006; ICAEW, 2006; Van der Veer, 2006).

It has been argued that structure endangers auditor judgement as it guides the auditor in what judgements to make and when to make them. Thus, the argument suggests that structure limits the scope of auditor judgement (e.g. Kosmala MacLullich, 2001; Turley and Cooper, 1991); "[i]n other words, in such a context judgement appears to end where structure ends" (Kosmala MacLullich, 2001:6). However, it could also be argued that the decision to follow guidelines and the way in which to follow them, and so on lies with the individual auditor in individual situations and that structure, serving as a guide for judgements, therefore does not "end judgement" (cf. Kosmala MacLullich, 2001). This so-called structure-judgement debate is not new when it comes to auditor work; it deals with an issue that "goes to the very heart of 
professional practice and identity" (Power, 2003:382; see also Carpenter, Dirsmith, and Gupta, 1994). However, due to quite recent developments, such as increased structure, within the profession, the debate seems more relevant than ever. Such developments have led to concerns regarding the audit process, its effectiveness, and the usefulness of audits. For example, Power (2003:379) describes how the legitimacy of the audit is "under fire". One important question that has been raised is whether the space for judgement has been or will be reduced as a result of increased structure (cf. Marton, 2011). In Agevall and Jonnergårds’ (forthcoming) study, auditors working in smaller firms complained about this reduced space for judgement and reported that they have to devote a large amount of time to "nonsense", implying that the auditors' work was boring and routinised. They also talked about the risks of missing the key things in their auditing work and said that professional scepticism has faded away as management by documents has increased. Generally, it is assumed that to establish oneself in the audit profession, one needs to be able to balance between structure and judgement (Broberg, 2013). Yet understanding the nature of the relationship between the two remains in the shadows of auditing research.

\section{University education and work-integrated learning}

The idea of higher education rests primarily in providing theoretical and scientific knowledge, abstract and independent of a specific practice, and developing analytical and critical ways of thinking. Such knowledge forms an important base for the professions. Yet, the professionals' knowledge base is also composed of context-dependent practical knowledge, including a tacit dimension (cf. Brante, 1988; Grimen, 2008; Smeby, 2008), gained while working. The theoretical and practical knowledge is usually heterogeneous and an integration of important elements of knowledge will often be made by practical synthesis in relation to professional practical requirements (Grimen, 2008). Post-secondary graduates are caught between the university context and the working context. For theoretical knowledge to be of practical 
relevance and to be turned into action within the workplace, it needs to be recontextualisation (Smeby, 2008). Such a challenge can also be an important opportunity for learning.

Researchers argue that WIL can serve as a natural way of bridging the gap between the academy and practice because it integrates academic skills with those required by the labour market (Elias and Purcell, 2004; Karlsson, 2011). According to Barrie (2004), WIL usually aims at developing skills such as communication; ethical, social, and professional understanding; personal and intellectual autonomy; research and inquiry, as well as information literacy (i.e. context-dependent practical knowledge within a specific practice and the ability to fit into a specific context and adjust to the rules and routines of the workplace/profession).

While purely practical internships focus on acquiring both understanding and practical experience, WIL aims at stimulating interaction between the theory learned and the practical experience acquired. A core idea of WIL involves students going back and forth between their university and internship organisation, learning the analytical tools, and then applying them in evaluating job situations. We understand WIL as an interactive boundary crossing between the university education learning context and the professional workplace. Studying this meeting point and auditing students' experiences during and after their WIL provides an excellent opportunity to explore how students understand the role of structure within the audit firms in relation to professional discretion and judgement. In WIL, the students have opportunities to be trained and to develop the ability to use manuals and checklists, yet not at the expense of judgement. WIL challenges students' critical ability by having them reflect over why they used manuals and checklists and the consequences of their use were. Based on this discussion, we posit that WIL might serve as an educational tool of dual learning which potentially stimulates understanding of the relation between judgement and structure. 


\section{Dual learning}

Dual learning can be defined as a way of educating people in practice-oriented professions combining "practice-oriented and theoretical learning in Higher Education" (DAAD, 2015). According to Biesta (2010) the concept of dual learning (not to be confused with the concept of double learning) highlights the difference between on the one hand education as qualification and socialization seen from within a professional order and subjectification on the other hand which means becoming a subject regardless of that professional order. Biesta (2010), poses that education fulfils three related and aforementioned functions: qualification, socialisation, and subjectification. Qualification involves equipping students with knowledge, competence, and understanding, as well as the inclination to do something. Socialisation involves, for example, transferring certain norms and values of professional socialisation systems to students as they become incorporated into existing ways of doing and being. Subjectification involves the process of becoming a subject where the individual is independent of existing ways of thinking, doing, and being. In the form of critical investigation and reassessment it is also an integral part of knowledge formation (e.g. Molander, 1993) while integrity, independence, and professional scepticism are also important for auditors' ethical consciousness (Baldvinsdottir \& Johansson, 2006).

Irrespective of whether qualification, socialisation, and subjectification are seen as entwined or as separate functions, they include what we mean by dual learning - the ability to use standards, checklists, etc., but also the ability to apply critical thinking and discretional judgment. Professionals have to evaluate the assumptions behind the rules, quality measures, and claims of best practice; they need to be able to appraise and understand how a particular technology influences their work (Aili and Nilsson, 2015). The research framework of this paper can be expressed by the model in Figure 1. 


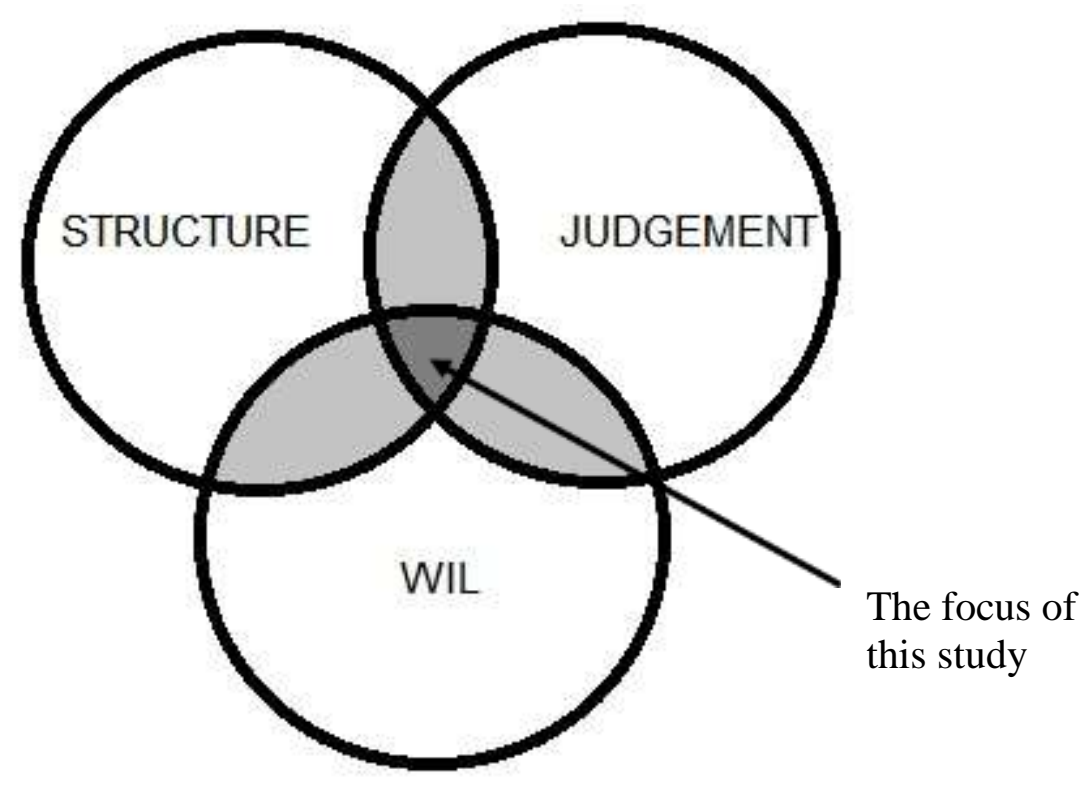

Figure 1 - Focus of the study

\section{Methodology}

\section{Method}

This paper employs a qualitative method of inquiry, inspired by the phenomenological hermeneutic approach (Dahlberg, Dahlberg \& Nyström, 2008). Our aim is to understand participants' experiences and their interpretation of those experiences. A number of specifically crafted situations, all related to auditing, were presented to students to discuss and reflect upon, based on the experiences they had prior to and during their WIL. Following the suggestions of Gaddamer (1997) and Ödman (2007), the authors also considered their own pre-understandings and the potential influence of these pre-understandings on their interpretation of the data.

\section{Participants}


The participants in this study were five master's students in the accounting and auditing programme at a small university in southern Sweden. Participation was voluntary: 20 students who participated in the WIL course were invited by email to participate. The email and the information letter explained that the study's aim was to explore students' experiences during their WIL; the students were also provided with an outline of the study. The five students, or one fourth of all students performing WIL that semester, who agreed to participate in the discussions received a further explanation of the purpose prior to the interviews. The only inclusion/exclusion criteria were that the students had to perform WIL prior to the interviews and have been active during the spring semester 2013 (the study period). Three of the five participants had been performing their WIL at audit firms, while the other two had observed the work of the auditor who was working at the organisation where they performed their WIL. The participants' ages ranged from 25 to 32 and there were two male and three female participants. Prior to conducting the study, the authors were granted ethical approval.

The WIL course has been developed and designed to enable as much dual learning as possible. During the 10-week long WIL course, the students divided their time between the university and their WIL placement. They spend their time the university attending seminars and lectures, studying literature and theory, planning/preparing empirical data collection, sharing experiences, and writing reflections and spend their time at their WIL-organization doing things such as observing routines, interactions, and the use of different tools. The students usually try out different manuals, checklists, and tools (often computer-based) and are given real tasks or authentic case assignments to work with and report on. The main examination consisted of an individually written course report in which they take on one or more problems that they had identified before or during the WIL course. In the report, they are to use empirical data from the WIL placement as well as the literature and theory learned at the university to discuss their problem(s). 


\section{Data collection}

Focus group was first used to collect the data (Krueger \& Casey, 2009); in addition, personal semi-structured interviews were conducted two weeks after the focus group to allow the participants to elaborate on their own answers and to reflect on the discussions in the focus group sessions. The focus group took place during the spring semester 2013 at the conference room of the university where the students were enrolled; two researchers (both female) not previously known to the students moderated the discussion. The discussion lasted for two hours, was voice-recorded, and later transcribed verbatim.

The focus group was used to explore participants' experiences in an interactive way, thus using this technique to have a "group effect" (Carey \& Smith, 1994) where experiences are presented, discussed, and elaborated upon in interaction with other group participants. This provides a rich database for analysis (Hollander, 2004). The authors of this paper are aware of some criticism put forward by some researchers (e.g. Webb \& Kevern, 2001) that find phenomenology to be incompatible with focus group interviews. However, in line with Bradbury-Jones, Sambrook, and Irvine (2009), we argue that experiences are seldom individually based and usually are a product of interaction between the self and the environment. We further argue that by elaborating on the experiences in the group rather than only in one-on-one interview settings, participants are able to relate to each other's experiences and so produce a richer and more comprehensive picture of their reality (Schmidt \& Umans, 2014). To address some limitations of the focus group sessions (potential group pressure and differences in communication styles among the participants), personal face-toface interviews were also conducted; only four participants of the initial five were available for them. During these interviews, the participants were asked to elaborate on their own answers from the focus groups as well as to discuss other participants' experiences vis-à-vis their own. 
A topic guide (Polit \& Beck, 2012) was prepared in advance. The first part of the guide covered concepts such as profession, auditing, manuals, and so on, which form a part of the auditor's vocabulary. The participants were asked to reflect on what the topics meant for them and to share their experiences with these concepts during the WIL. The second part of the guide had a number of situations/examples that typically would occur in the auditor's day-today activities (Broberg, 2013); students were asked to relate to the situations and to describe their own experiences in similar situations.

While this study is based on one focus group discussion and four interviews, which could be considered rather limited empirical material, we have a number of reasons why it might be considered sufficient in this study. Firstly, this study aims at exploring experiences and perceptions of the students from within one given situational context (i.e. WIL). In other words, the rarity of occurrence of the event/context might justify a smaller sample (Crouch \& McKenzie, 2006; Marshal, 1996). Secondly, the explorative nature of the paper implies that the aim is to understand the meanings students attach to concepts such as structure, judgement and audit profession, as well as the sense making students go through during their WIL period. According to Crouch and McKenzie (2006) in these types of studies, smaller samples are not only acceptable but also required, given the depth of understanding wanted. Finally, a smaller sample was deemed appropriate since we sought to not only understand the experiences of each student, but also try to explore their joint experiences during the WIL and their understanding and interpretation of the concepts under study. According to Schmidt and Umans (2014), a small "group effect" provides valuable data for generating a deeper understanding of the phenomenon under study and may be facilitated in a group of four to five (Côté-Arsenault \& Morrison-Beedy, 1999).

\section{Analysis}


The analysis, inspired by Dahlberg et al. (2008), was divided into three stages. During stage one, all the transcribed interviews were read and the dialogue with the text began, while interpretation was avoided ${ }^{\text {iii }}$. Stage two began and resulted in a structural analysis (Lindseth \& Norberg, 2004) with emergence of hermeneutic themes. This process was repeated several times to ensure the validation of understanding. In stage three, the themes were reviewed from a more holistic perspective and merged into a new understanding (cf. Dahlberg et al., 2008).

It is important to note that the authors had certain pre-understandings in the field that could have influenced the analysis. They have either taught or published on auditing-related topics and had their own views on the interaction between structure and judgement and on the meaning of professional conduct in the audit profession. They tried to "manage" their preunderstandings by being open to the experiences revealed by the participants and avoiding being judgemental. In the process of inter-researcher interaction, the authors attempted to see the data from different perspectives. The analytical process consisted of periods in which they engaged in collaborative as well as individual interpretative work, which allowed the interpretations to be tested. Such an iterative process both enabled and restrained interpretative creativity (cf. Weick, 1989)

\section{Empirical findings}

Our analysis was formed in line with two meta-themes derived from the empirical material. We call them Perceiving the profession and the professionals and Entering into and forming in the profession. These meta-themes were divided into sub-themes, which in turn, when appropriate, were divided into number of analytical units. This division is illustrated in Table 1 - Empirical Findings.

\section{Table 1: Empirical Findings}




\begin{tabular}{|c|c|c|}
\hline Meta-themes & Sub-themes & Units \\
\hline \multirow{2}{*}{$\begin{array}{l}\text { Perceiving the } \\
\text { profession and the } \\
\text { professionals }\end{array}$} & $\begin{array}{l}\text { The students' ideal picture of } \\
\text { profession/professionalism }\end{array}$ & $\begin{array}{l}\text { Specific knowledge - an expertise } \\
\text { Professional norms and ethics } \\
\text { Independent work }\end{array}$ \\
\hline & Another picture of professionalism & $\begin{array}{l}\text { Professionalism contra } \\
\text { commercialism } \\
\text { Auditors become sellers } \\
\text { Quality is another thing }\end{array}$ \\
\hline \multirow{2}{*}{$\begin{array}{l}\text { Entering into and } \\
\text { forming in the } \\
\text { profession }\end{array}$} & $\begin{array}{l}\text { Differences in experiencing the gap } \\
\text { between theory and practice }\end{array}$ & \\
\hline & $\begin{array}{c}\text { The clash between structure and } \\
\text { judgment }\end{array}$ & $\begin{array}{l}\text { Structure and judgment in conflict } \\
\text { Structure and judgment in harmony }\end{array}$ \\
\hline
\end{tabular}

\section{Theme: Perceiving the profession and the professionals}

In the theme Perceiving the profession and the professionals, the students revealed their ideal and experience-based view of the audit profession and of auditors (the professionals) and their tasks. Here one can observe how clashes of the ideal and the reality affected students' experiences during their WIL. The sub-themes are the students' ideal picture of profession/professionalism and another picture of professionalism, each of which are composed of three units (see Table 1).

Sub-theme: The students' ideal picture of profession/professionalism 
When reflecting on the profession and professionalism, the students highlighted education and qualifications as well as the importance of both theory and experience (having significant knowledge) and continuous professional development. We interpreted these observations as students' talking of knowing, which reflects an active side of knowledge. Additionally, the students emphasised the significance of social and interaction skills. Together these reflections represent one unit of the students' view of auditors: Specific knowledge - an expertise. In this sub-theme they also reflected on the units professional norms and ethics as well as on the expectations and advantages of independent work.

Specific knowledge - an expertise When describing why auditing is a profession, the participants proposed that it requires a specific knowledge and understanding, for example, [...] a comprehensive knowledge that is very specific and cannot be possessed by whomever. They also said that in order to perform auditors' duties, one needed to have expert knowledge, that is, special theoretical knowledge combined with work experience. The students emphasised the importance of knowledge and a professional way of thinking. They said that the work is not only about auditing numbers and but, more important, it is also about seeing how one came to these numbers and how the audited organisation functions [...]. This can be interpreted as a conscious awareness of the need for attention, assessment, and understanding of the specific context in each case.

Students also said that to be able to enter the industry, one needs to have a specific type of education [...] I must be an expert. [...] If one wants to become an authorised auditor, one must get continuous education within the auditing firm. Students saw the authorisation process of the auditor as an important cornerstone of building auditors' legitimacy.

Students also mentioned that knowledge, experience, and expertise are what set the limits of as well as define the profession. As one student stated, ... in the profession, one usually holds 
certain things to oneself in order to maintain the status of the profession. This reasoning indicates that expertise and knowledge were seen as tools in limiting access into the profession as well as defining its borders vis-à-vis other professions. Moreover, it appears that students recognised the profession's jurisdiction and the importance of the profession's jurisdiction in monopolising auditing in the market. Students further said that experience and knowledge development are the ways to develop the profession, rather than just a way to close it to others:

[...] if one is an auditor and one gets into a firm, and then one is working in this firm for the next 10 years. One gets a lot of knowledge that is difficult to convey and transfer, but which you can use to further develop a profession. So by developing oneself and the profession, one automatically forces the others in the profession to develop. Which in turn means that it is hard to eliminate the borders of the profession [...] since it is hard to get the knowledge elsewhere. In a way then, the profession is something that is being built on the knowledge within and about the profession.

As part of this sub-theme, the students also reflected on the importance of social skills and being able to interact with clients. One student described an auditor's professionalism as follows:

The distinctive feature for his professionalism was that if he found something wrong he started a dialogue, a fine dialogue, a fine discussion. [...] it was often - in agreement with what he and the client will have to do to solve the issue. The fact that he got involved in a dialogue $[\ldots]$ that can also mean professionalism to know in which situation to act in which manner.

The same student continued: 
It is important to be good with people. I couldn't imagine in the beginning of my education that it would be so important; instead, I thought that it [auditing] is about the ability to count, more like in accounting, like bookkeeping.

This student learned by example and recognised some important features of the professional auditor. The student understood that the auditors' knowledge base has many sources - not only in accounting and auditing theory, laws, taxes, and so on, but also, for example, in communication theory/skills and social competence. The student had learned the importance of social skills - that the knowledge base includes being good with people .... And that can also mean professionalism - to know in which situation to act in which manner. That is important for a professional auditor.

It appears that the students' perceptions of the audit profession were at first dominated by the notion of knowledge and expertise but that after they had their WIL, it also included the importance of continuous education within the audit firm to acquire further practical knowledge and skills as well as the importance of developing social and interaction skills.

Professional norms and ethics Drawing a complex picture, the students put forward the notions of moral objectivity, honesty, integrity, and meticulousness as important definers of a professional auditor. They spoke of this in combination with the confidentiality that the auditor should maintain towards information related to the client. In addition to talking about the auditor as an individual, the students also mentioned the importance of the auditor as a part of the normative fellowship that shared similar values and approaches. During the interviews, the students tried to reflect on where they had personally developed their own ideas about the importance of internalisation and socialisation as part of professional values. It appears that they acquired this notion from their courses at the university rather than from their WIL - the auditors they had met did not appear to have discussed this aspect of the 
profession. Moreover, the students claimed that they had understood importance of the ethical aspects of the profession from the literature, rather than from discussions with auditors during their WIL.

Independent work The students saw independence in work as an important hallmark of the professional auditor, and they often referred to the auditor's degree of freedom as an important indication of professionalism. Students emphasised freedom of thinking and taking responsibility as pre-requisites for becoming an auditor as well as for being one. Students discussed the positive aspects of choosing the profession, such as an expectation of independent work and a high degree of responsibility: That you can plan your own work, you can vary your work, you meet new customers all the time - to be professional, to help people.

\section{Sub-theme: Another picture of professionalism}

In reflecting on the meaning of a profession and professionalism, students often went back to their experiences in meeting auditors and auditor assistants during WIL. Students' critical reflections on these distinctions are described in terms of three units: professionalism contra commercialism, auditors become sellers and quality is another thing.

Professionalism contra commercialism The students discussed whether professionalism and cost efficiency could co-exist. It was surprising to them that the auditors they met saw no problem in being professional and cost-efficient and that auditors did not even reflect on this:

They [the auditors] always talk about the importance of speed of work. [...] Yes, for them that was professionalism. Before that, I never thought in such a way. I thought professionalism was about a lot of knowing and an ability to help them [clients], but almost never do they [the auditors] talk about it.

In the discussion the students talked about their previous impression of the profession - that one has to do the right thing - and their new impression that auditors mostly talk about being 
cost-efficient. Yet the students also said that they found the flexibility in counting the time spent with the client to be an important ability a professional auditor should have, since doing right should, in their view, be prioritised. When asked to reflect on how they gained image of professionalism as cost-efficient work, the students agreed that they had experienced it during the WIL period.

Auditors become sellers During their WIL, students also observed that the auditing assistants were more engaged in auditing than the auditors. The auditors gave instructions to the assistants; the students suggested that the auditors were taking on more of a sales function:

[The auditor] who has knowledge in auditing [...] becomes a seller while the newly employed do the auditing work; [...] the auditor checked their work and signed it.

They observed that an auditor has some responsibility for finding new customers by offering an estimated price, which surprised the students. The audit has a price tag as any other product or service - which ultimately makes a seller out of the auditor and the audit has become a commodity.

Quality is another thing Students also had critical reflections about what quality means within the audit firms:

- If the customers were pleased, that is good for the audit firm and then the quality was high. They understand it as the same thing; customer pleased, short time for the job, and the job should not cost too much.

- One must be there for the customer. Always.

- Yes, you have to prepare your readings [before the visit]; you have to be professional. To be professional is the same as these three things [...] but a short time and low cost may influence and reduce the audit quality. 
- It all depends on what you mean by "audit quality."

- Yes, but I think that audit quality is to do the right thing, finding faults, mistakes.

- Yes.

- [If an estimated price is offered] it will be important to keep the promise, thus they make, so as to say, some modifications (....) to how much one has to look / control.

As we have seen, the students were somewhat disappointed when observing and discussing what auditors actually do today. Some students said that after seeing the practice during their WIL, their views on the audit profession had changed.

\section{Theme: Entering into and forming in the profession}

In the theme Entering into and forming in the profession, students compared their education at the university with their experience during their WIL or, as the students called it, theory and practice. They experienced the gap between theory and practice and observed some conflict between the use of structure and judgement. The outcomes of our interpretation of this theme are described in two sub-themes: Differences in experiencing the gap between theory and practice and The clash between structure and judgement (composed by two units, see Table $1)$.

Sub-theme: Differences in experiencing the gap between theory and practice

In the sub-theme Differences in experiencing the gap between theory and practice, students reflect on their experiences of the discrepancies between theoretical knowledge and practice: 
At the university, we get lots of theoretical knowledge; then during WIL, we get an idea of how the industry functions. One gets the idea [...] and many times one has an "oh my" experience, "so that's how they do it".

The students had varied opinions about the instrumentality of the theoretical courses for the WIL:

It felt embarrassing to go there and not know. It felt that one needed more education, i.e. courses that one could have benefitted more [...] IT and management, cost accounting, maybe $[\ldots]$.Yet I felt that I learned a lot during the WIL. [...] So much was happening there just during one day [...].

The same student said one problem was the lack of a course describing what auditors do; thus, the student experienced what they saw in the WIL as new. Another student disagreed, saying that accounting courses had given them a good base in that they had learned how annual reports and financial statements are presented. This student felt they were prepared in their understanding of what auditors do through three courses (Accounting I and II and Accounting Theory), although the auditing course material and the auditing reality might be different. The student thought it might be hard to explain in detail in university courses what the auditor actually does. Yet another student added to this debate; this person had not found the theoretical knowledge learned at the university very useful at the WIL placements. The student did say that the theory had provided them with a knowledge base that enabled them to discuss issues using the same terminology as the auditors used in their daily work. Thus, the "jargon" the students learned at the university appeared to be useful during their WIL. The same student said that they had to learn principles of financial accounting, yet the auditing assistants they were observing never even mentioned them; instead, they simply followed checklists and filled out the forms. The students also commented that they were unprepared to work with manuals. 
The sub-theme The clash between structure and judgement describes how students experienced conflicts between structure and judgement in the audit work. During their WIL, students observed how the work of an auditing assistant was driven by what the supervisor said, what the audit software required, and by the manuals and checklists. The students also spoke about the use of manuals, where they confronted the use of judgement and structure. To describe how students understood the relation between structure and judgement, we have divided this sub-theme into two interrelated units: Structure and judgement in conflict and Structure and judgement in harmony.

Structure and judgement in conflict The students were very critical about what auditing assistants do (e.g. follow the manuals) and don't do (e.g. their own evaluations). One student was amazed at how limited the auditors were in what they checked in the information from the client.

Overall, the students perceived the auditing assistants' work as being routinised, performed within a limited framework, and not requiring the qualifications that the assistants possessed. One student thought that the assistant observed did not really need an education for the job.

I had a tutor, who had been there for three years, and after two days, I could do quite a lot of her stuff because she also had a form that she followed. Of course, I had to ask a lot, but she had made a binder where she included the answers from the auditor who was the engagement leader ${ }^{\text {iv }}$ who was her supervisor; she had typed up everything he had said. [...] She also had a specific form which she used as a template, and if she didn't get something, she had always an opportunity to ask the engagement leader about it.

Students believed that the auditing assistants did not exercise little professional judgement: 
If one looks at the auditing assistants, it appears that they hardly use any professional judgement, since everything appears to be "structure" ... Yes, the computer-based auditing software, checklists [...].

Furthermore, the students were critical of the way the manuals were used. One pointed out that it was difficult to produce a manual relevant for all clients:

They had one manual and they apply that manual to all [clients]. [...] so you can miss the entirety.

Another student agreed and said that the ability to think critically might be affected in a negative way. Students pointed to the importance of context-dependent knowledge and of being sensitive to the necessity of adapting the work for specific circumstances. They appeared to approach the concept of "one size fits it all" critically, suggesting that a more professional approach might be related to individual approaches to specific clients.

Students further discussed how manuals and checklists might reduce the thinking, learning, and level of responsibility of the auditor:

It seems to be the same type of knowledge that goes around all the time, so nothing is actually new under the sun.

It must be like that in all firms ... that at the end everything becomes the same.

In the students' experience the manuals represented static knowledge and left no space for potential creativity and innovation.

We interpreted the students' comments as critical reflections about an extensive use of structure, which is partly due to an exaggerated socialisation - a threat to the continuous development of knowledge - the active side of knowledge - knowing. 
Students also observed that if the client firm has been audited before, the auditing assistants do it as it has been done previously; if the auditor does not say that anything extra has to be done, the auditing assistant follows the manual.

Furthermore, the students said:

If one follows the checklist, you do not need to think much.

The checklist is a way to reduce the responsibility of the auditor assistants.

One student said that auditor assistants have to learn to see/recognise what is wrong. The assistants should be allowed to work with the law instead of a checklist (i.e. audit firm developed specific lists, interpreting and "concretizing" the law and the auditing standards), but that this may take longer time. This student was making a connection between the strong demands for speed and cost efficiency and the use of manuals and checklists curbing the learning process and ability to make assessments and decisions:

... judgements doesn't just appear [...] I think all those that are new now lost on the professional judgement.

Students critically reflected over what is at risk here and how it affects newcomers to the profession: there is a risk that the professional judgements simply disappear with the use of software programs. The dominance of structure, they observed, reduces the space for judgements, and students experienced this effect as diminishing rather than improving the profession.

The students also discussed the reduction in commitment stemming from what they perceived to be manual work. 
One actually learns what one should do and is allowed to do [...] I think one can be influenced in a negative way though, [...] like the assistants that have ready-made frames $[\ldots]$ which they base their judgement on $[\ldots]$ it just becomes $[\ldots]$ monotone.

Ready-made frames will reduce the commitment to auditing work.

Students also said auditors' assignments involved a lot of copy/paste work. A student quoted an auditor assistant: We erase here and put this number there instead. And there are the same types of sentences we include in all company reports.

One student spoke about an incident at the municipality where he had done his WIL. The municipality had changed audit firms after finding that the audit report it received still included the name of another municipality the firm was auditing. Names of committees were also wrong so the mistakes were clearly a result of the copy/paste system. The students were very critical of such practices. Moreover, they questioned whether the use of the copy/paste system and changing numbers is appropriate when bringing new people into the profession.

Structure and judgement in harmony In the sub-theme structure and judgement in harmony, the students observed that the relation between structure and judgement would change with time and experience and might harmonise.

Students observed that in spite of their doing manual work, the auditor assistants could answer most of their questions: [...] we do it like that because blah, blah, blah. In other words, they had learned from manuals, checklists, and programmes. The students thought that structure might also be good for newcomers:

One learns a lot [by using the manuals] since one goes through all the steps that are recommended. Then one has done what is needed. One has gone through all the items or yes, one has taken into account all the parts. 
Students agreed that manuals are necessary in the beginning: ... maybe it [structure] is just in the beginning, and that with more experience the relation between structure and judgement would change. They expressed an expectation that the ability to apply one's own judgement would come with experience:

... maybe it [the manual work] is just in the beginning .... When one is new to the field, maybe one just does the structural work; then it is more and more slanted towards judgement.

... yes, I think that the longer is the auditor connected to the same audit firm, the more I think they acquire the professional judgment.

Students argued that the longer an auditor's tenure in the firm, the more scope for professional judgement they appeared to have and use. Students implicitly talked about experience as a process of learning practical knowledge and skill and developing the ability to make independent judgements. They also observed that those in higher positions are allowed more judgement and responsibility.

However, one student also mentioned that an auditor with long experience found structure useful, that it facilitates the work:

I interviewed one of the auditors that have worked for more than 20 years. He thought that those structures (audit software programs) make it easier ... that their work becomes much easier. It takes less time and in this way they can concentrate on something else instead.

Thus, the students thought that the infusion of structure into the profession leaves less space for judgement and professional scepticism, while they realised the need to be socialised into it and the need for routinised practical work. At the same time, they were critical about how manuals could affect the audit work. 


\section{Conclusion}

This study has had two aims: to explore whether and how dual learning can help students' understanding of the relationship between structure and judgement and to explore students' perceptions of the audit profession.

The two themes, Perceiving the profession and the professionals and Entering into and forming in the profession, suggest that within the WIL context, students developed awareness of the use of standards and checklists on the one hand and the importance of discretional judgement on the other.

In Perceiving the profession and the professionals, students appeared to first put forward their ideal picture of auditing, discussing it in terms of expertise embedded in both theoretical and experience-based, context-dependent knowledge. They also showed they were aware that the relationship with the client is an importance a part of professional activity. In reflecting on the task of auditing, the students seemed to understand that professionalism means the ability to engage in a dialogue with clients as well as to address clients' needs. They also mentioned that professional norms and ethics and independence of thought and action were important. This picture might indicate students' anticipatory socialisation process (Heggen, 2008:322), where in interaction with each other and professionals during their WIL, the feeling of being groomed for a professional role is emphasised. The students also showed an understanding of how professional knowledge and skills are closely associated with strong identification with the profession. This resonates well with the idea of qualification for the profession put forward by Heggen (2008) and Evetts (2010). Evetts argued that "[p]rofessional values emphasise a shared identity based on competencies (produced by education, training, and apprenticeship socialization) [...]" (2010:125f). Similarly, the students also related the interaction between identity and expertise to the specific frames within which it takes place; 
this is closely related to the notion of professional discretion (Liljegren \& Parding, 2010). The emphasis on the ideal-typical characteristics of the profession or "occupational professionalism" (Evetts, 2010), emerged especially when students discussed their preunderstandings and expectations prior to WIL

In reflecting on their WIL experiences the students' views of the profession appeared to change: the critical discussion often circled around commercialisation and commercial practices infiltrating auditing firms and raised the question of whether professionalism and commercialism are compatible. The students discussed how cost and time-effectiveness; customers and orientation towards satisfaction of customer needs; as well as issues related to the meaning of quality and how it is created seemed to drive auditors' work. Students also discussed how the hierarchy in audit firms emphasised the clash between commercialism and professionalism. The lower levels of the hierarchy (e.g. audit assistants) usually perform the routine "mechanical" work, without any discretionary space, while at the top of hierarchy the auditors, who had more discretion and responsibility, performed commercial activities in making sure that customers are satisfied and the service is sold. The picture students appeared to draw was closely related to the notion of organisational professionalism, which emphasises rational-legal authority, hierarchical structures of authority, standardised procedures, decision making, and managerialism (Evetts, 2010). By experiencing this during their WIL, students' anticipatory socialisation seemed to be challenged in that the ideals with which they had started associating themselves did not correspond to the reality. Thus, students appeared to find themselves at an intersection between two conflicting logics in the construction of their professional identity. In dealing with these contradictions, students develop their understanding of structure and judgement and their relationship in the audit profession, and consequently come to realization as to what might constitute independence of work. 
In the theme Entering into and forming in the profession, students related their experiences with the interrelation between structure and judgement. It suggests that students could see the interaction between the two concepts in light of either conflict and harmony. The students mentioned that the work appeared to be monotonously guided by checklists and manuals and provided neither space nor time for critical thinking or reflection. They saw structure appearing to dominate the profession especially at the beginning of an auditors' career. The students questioned why one should not possess the ability to be flexible and have sufficient discretion and space for judgement to fulfil one's professional obligations. They also reflected that the level of hierarchy and experience in the firm allowed for more balanced interaction between structure and judgement. While they accepted that structure might come first in developing professional auditors, they saw the need for space to apply a certain degree of judgement in practice. Without it, they did not see the point in an academic education being a prerequisite for entering the profession.

We see a possibility of framing the discussion of the interaction between judgement and structure with the help of the concept of discretionary specialisation (Freidson, 2001). According to Freidson, professional tasks are often described as “... narrow, minute, detailed, or "specialized" [in] the range..." (2001:23) yet there is "necessity of altering routine for individual circumstances" (ibid) and thus a need to be able to perform discretionary judgement and action.

The students did not experience the conflicting and complementary nature of structure and judgement as mutually inclusive. Their discussions of the importance of structure for future use of judgement resonated well with the idea that structure represents a decision-support system, which might be a way of enriching judgements (Molander, Grimen \& Eriksen, 2012). We interpret their ability to see the interrelation in such a light as a result of their exposure to practice and direction in the WIL. Thus, the students appear to have experienced dual learning 
in the intersection between theory and practice, and displayed a capacity to analyse and make sense of these experiences.

We can also observe that during their WIL, students may create a unique picture of the audit profession. On the one hand, they conveyed admiration for the auditor's guardian role and being of service to the society, which they discussed in the frames of their expertise, professional norms, ethics, and independence. On the other hand, they see many contradictions between the role projected by auditors and how this transfers to actual practice in that the balancing act between structure and judgement appears to be a complex and difficult (e.g. Liljegren \& Parding, 2010).

Throughout this study, we observed the interrelated nature of higher education's assigned functions (Biesta, 2010): qualification, socialisation, and subjectification within which the dual learning is embedded.

Qualification as well as subjectification, deals with independent and critical judgement. To critically evaluate, re-evaluate, and question established assumptions is an integrated part of the formation of knowledge (Molander, 1993)

Simultaneously, the socialisation process within the audit profession is understood in terms of independence, respect, objectivity, integrity, and professional scepticism. Ethical awareness is embedded in these concepts and it is important for the profession that its members develop such qualities (Baldvinsdottir \& Johansson, 2006).It appears that from the profession's viewpoint, the subjectification process is closely interrelated to qualification and socialisation; qualification, socialisation, and subjectification are closely intertwined in the development of professional identity

Another aspect of subjectification as argued by Biesta (2010) could be understood as the opposite of socialisation, in that the new entrants into the profession are not only introduced 
to the existing practices (i.e. socialisation), but also encouraged to show a certain degree of independence from the established order of things (i.e. subjectification). Thus, the separation of and conflict between socialisation and subjectification represent important education functions that develop future professional skills.

Our study shows there might be a third way of understanding the relationship between the three functions. Here we suggest that the concept of dual learning in the example of WIL shows how both the detachment and interrelation between functions serve the purpose of higher education at different times. Sometimes detaching socialisation and subjectification serves its purpose in that prior to WIL, subjectification is emphasised, and students are encouraged to critically approach information received, while during the WIL placements the socialisation function is emphasised, especially when it comes to understanding the importance of structure vis-à-vis judgement. In going back and forth between the university and WIL placements, students appear to experience both the detachment and interrelation of the different functions, which resulted in their ability to adhere to established routines at the workplace, while questioning them.

As an exploratory study, this paper gives rise to more questions than answers. We feel there is scope for further exploration and explanation as to how, for example, students' development of understanding and experience of professions will progress in the real world. Future studies could also look at identity formation of the new generation of auditors. Further research might look into how learning and its various aspects develop prior to, during, and after WIL. It would be also interesting to see further inquiries into differences between programmes leading to professional degrees with and without WIL, in terms of their ability to develop professionals. Studies should also explore the structural aspects of WIL in different professional programmes and their relationship to dual learning. 
This study is not without limitations especially when it comes to validity threats in using qualitative methodology and being based on a small sample. To address threats to credibility and authenticity, we chose interviewers the students did not know; gave the student confidentiality to facilitate open dialogue during the interview; and were in a constant dialogue with each other about our pre-understanding and assumptions in relationship to analysis performed. To address threats to criticality and integrity, we established a strict design for the study and were especially attentive to the differences of opinions both within the authors team and among the interviewees. We have further performed a number of backwards loops in interpreting and re-interpreting the data; we have also put our own interpretation forward as just one way of understanding the phenomenon, rather than making statements of causality or fact. We aimed at openness to the data as well as technical and research process transparency, which are considered to be most instrumental in increasing the validity of an investigation (Whittemore et al., 2001) 


\section{References}

Agevall, L. (1994). Beslutsfattandets rutinisering. Lund: Lunds universitet, Lund Political Studies 84 .

Agevall, L., \& Jonnergård, K. (2007). Management by documents - a risk of deprofessionalizing? I C. Aili, L-E. Nilsson, L. G. Svensson, \& P. Denicolo (Eds.), In Tension between Organization and Profession. Professionals in Nordic Public Service. (33-55). Lund: Nordic Academic Press.

Agevall, L., \& Jonnergård, K. (2012). Från förtroende för revisorsrollen till förtroende för revisionsstandarder? I C. Björngren Cuadra, \& O. Fransson (Eds.), Tillit och förtroende ständiga utmaningar för professioner (131-158). Malmö: Gleerups Utbildning AB.

Agevall, L., \& Jonnergård, K. (Forthcoming) Erfarna revisorer berättar, Linnaeus University Press.

Aili, C., \& Nilsson, L-E. (2015). Dual learning - a challenge for higher education in the new landscape of governance. Tertiary Education and Management, 21(4): 277-292.

Baldvinsdottir, G., \& Johansson, I-L. (2006). Förtroende som illusion - skärpt reglering av revision? I I-L. Johansson, S. Jönsson, \& R. Solli, (Eds.) Värdet av förtroende (245268). Lund: Studentlitteratur.

Barrie S. C. (2004). A research-based approach to generic graduate attributes policy. Higher Education Research and Development, 23 (3), 261-275.

Biesta, G. J. J. (2010). Good education in an age of measurement: Ethics - politics democracy, Boulder, CO.: Paradigm Publishers.

Björklund, L-E. (2008). Från novis till expert: Förtrogenhetskunskap i kognitiv ochdidaktisk belysning. Linköping: Linköpings univeritet, Utbildningsvetenskap. 
Bradbury-Jones, C., Sambrook, S., \& Irvine, F. (2009). The phenomenological focus group: An oxymoron? Journal of Advanced Nursing, 65(3), 663-671.

Brante, T. (1988). Sociological Approaches to Professions. Acta Sociologica, 31(2), 119-142.

Broberg, P. (2013). The auditor at work: a study of auditor practice in Big 4 audit firms. (Doctoral dissertation, School of Economics and Management, Lund University).

Bowrin, A. R. (1998). Review and synthesis of audit structure literature. Journal of Accounting Literature, 17, 40-71.

Brunsson, N., \& Jacobsson, B. (Eds). (1998). Standardisering. Stockholm: Nerenius and Santéus förlag AB.

Carey, M. A., \& Smith, M. (1994). Capturing the groups effect in focus groups: A special concern in analysis. Qualitative Heatlh Research, 4, 123-127.

Carpenter, B. W., Dirsmith, M. W., \& Gupta, P. P. (1994). Materiality judgments and audit firm culture: Social-behavioral and political perspectives. Accounting, Organizations and Society, 19(4), 355-380.

Carrington, T., \& Catasús, B. (2007). Auditing Stories about Discomfort: Becoming Comfortable with Comfort Theory. European Accounting Review, 16(1), 35-58.

Côté-Arsenault, D., \& Morrison-Beedy, D. (1999). Practical advice for planning and conducting focus groups. Nursing Research, 48(5), 280-283.

Crouch, M., \& McKenzie, H. (2006). The logic of small samples in interview-based qualitative research. Social Science Information, 45(4), 483-499.

DAAD. (2015). “Dual Learning” Combining Practice-Orientated and Theoretical Learning in Higher Education. Summary of workshop discussions/proceedings from European expert seminar organised by the Permanent Representation of Germany to the EU and the German Academic Exchange Service (DAAD) on Monday, 20th April 2015 in Brussels. Retrieved from 
http://bruessel.daad.de/medien/bruessel/veranstaltungen_2015/summary_expert_semin ar_on_dual_learning_20april2015.pdf

Dahlberg, K., Dahlberg, H., \& Nyström, M. (2008). Reflective lifeworld research. Lund: Studentlitteratur.

Eklöv, G. (2001). Auditability as interface: negotiation and signification of intangibles. Stockholm: Stockholm University, School of Business.

Elias, P., \& Purcell, K. (2004) Is mass higher education working? Evidence from the labour market experiences of recent graduates, National Institute Economic Review, 190, 6074.

Evetts, J. (2010). Reconnecting professional occupations with professional organizations: risks and opportunities. Sociology of Professions: Continental and Anglo-Saxon Traditions, 123-144.

Freidson, E. (1994). Professionalism reborn: Theory, prophecy and policy. Oxford: Polity Press.

Freidson, E. (2001). Professionalism. The Third Logic. Cambridge: Polity Press.

FRC. (2006). Promoting Audit Quality. Discussion paper. Financial Reporting Council, November 2006.

Gadamer, H.-G. (1997). Truth and method. New York: Continuum.

Gibbins, M. (1984). Propositions about the psychology of professional judgment in public accounting. Journal of Accounting Research, 22, 103-125.

Grimen, H. (2008). Profesjon og kunnskap. I A. Molander, \& L-I. Terum (Eds.) Profesjonsstudier (71-86). Oslo: Universiretsforlaget.

Heggen, K. (2008). Social workers, teachers and nurses-from college to professional work. Journal of Education and Work, 21(3), 217-231. 
Hollander, J. A. (2004). The social contexts of focus groups. Journal of Contemporary Ethnography, 33(5), 602-637.

Humphrey, C., \& Moizer, P. (1990). From techniques to ideologies: an alternative perspective on the audit function. Critical Perspectives on Accounting, 1(3), 217-238.

Institute of Chartered Accountants in England \& Wales (ICAEW). (2006). Audit quality fundamentals - Principle-based auditing standards.

Karlsson, L. (2011). Academic quality and internships. Students' account on the value of theory in practice. Learning Communities: International Journal of Learning in Social Contexts, 1, 4-21.

Knechel, W. R. (2007). The business risk audit: Origins, obstacles and opportunities. Accounting, Organizations and Society, 32(4), 383-408.

Kosmala, K. (2005). Insights from Ricoer's Hermeneutics on Best Practice in Professional Service Firms: On Perpetual Myth Creation? Quality Sociology Review, 1(1), 31-50.

Kosmala MacLullich, K. (2001). Dynamics between judgment and structure in formative years in audit practice: Insight from hermeneutics. Edinburgh, UK: Heriot-Watt University.

Kosmala MacLullich, K. (2003). The emperor's 'new' clothes? New audit regimes: insights from Foucault's technologies of the self. Critical Perspectives on Accounting, 14(8), $791-811$

Krueger, R. A., \& Casey, M. A. (2009). Focus groups: A practical guide for applied research. Thousand Oaks, CA: Sage.

Larson, R. K. (2007). Constituent participation and the IASB's international financial reporting interpretations committee. Accounting in Europe, 4(2), 207-254.

Levay, C., \& Waks, C. (2009). Professions and the pursuit of transparency in healthcare: two cases of soft autonomy. Organization Studies, 30(5), 509-527. 
Liljegren, A., \& Parding, K. (2010). Ändrad styrning av välfärdsprofessioner-exemplet evidensbasering i socialt arbete. Socialvetenskaplig tidskrift, 17(3-4), 270-288.

Lincoln, Y. S. (1995). Emerging criteria for quality in qualitative and interpretive research. Qualitative Inquiry, 3, 275-289.

Lincoln, Y. S., \& Guba, E. G. (1985). Naturalistic inquiry. Newbury Park, CA: Sage.

Lindseth, A., \& Norberg, A. (2004). A phenomenological hermeneutical method for researching lived experience. Scandinavian Journal of Caring Sciences, 18(2), 145153.

Maclullich, K. K. (2001). The impact of non-audit services and audit process standardisation on independent audit judgement and fraud recognition (Doctoral dissertation, University of Edinburgh).

Marshall, M. N. (1996). Sampling for qualitative research. Family Practice, 13(6), 522-526.

Marton J. (2011) Slutet för den professionella revisorn? Balans, 3, 26-27.

Mennicken, A. (2005). Sociology of accounting,. In J. Beckert, \& M. Zafirovski (Eds.), International encyclopaedia of economic sociology (1-5). London: Routledge.

Mennicken, A. (2008). Connecting worlds: The translation of international auditing standards into post-Soviet audit practice. Accounting, Organizations and Society, 33(4), 384414.

Molander, B. (1993). Kunskap i handling. Göteborg: Bokförlaget Daidalos.

Molander, A., Grimen, H., \& Eriksen, E. O. (2012). Professional discretion and accountability in the welfare state. Journal of Applied Philosophy, 29(3), 214-230.

Ödman, P.-J. (2007). Tolkning, förståelse, vetande: Hermeneutik i teori och praktik Stockholm: Norstedts Academic Publishing House.

Öhman, P. (2006). Perspecktiv på revision: tankemönster, förväntningsgap och dilemman.Sundsvall: Mittuniversitetet (Doctoral thesis,, Mid Sweden University) 14. 
Öhman, P., Häckner, E., Jansson, A. M., \& Tschudi, F. (2006). Swedish auditors' view of auditing: Doing things right versus doing the right things. European Accounting Review, 5(1), 89-114.

Pentland, B. T. (1993). Getting comfortable with the numbers: Auditing and the microproduction of macro-order. Accounting, Organizations and Society, 18, (7/8), 605620.

Polit, D. F., \& Beck, C. T. (2012). Nursing research: Generating and assessing evidence for nursing practice. Philadelphia, PA: Lippincott Williams \& Wilkins.

Power, M. (1997). The audit society. rituals of verification. Oxford: Oxford University Press.

Power, M. K. (2003). Auditing and the production of legitimacy. Accounting, organizations and society, 28(4), 379-394.

Sahlin-Andersson, K. (2006). Transparensens former. I C., Levay, \& C., Waks (Eds.), Strävan efter transparens (19-50). Stockholm: SNS. Förlag.

Schmidt, M., \& Umans, T. (2014). Experiences of well-being among female doctoral students in Sweden. International Journal of Qualitative Studies on Health and Well-being, 9.

Smeby, J-C. (2008). Profesjon og utdanning. I A. Molander, \& L-I. Terum (Eds.), Profesjonsstudier (87-102). Oslo: Universitetsforlaget.

Smith, M., Fiedler, B., Brown, B., \& Kestel, J. (2001). Structure versus judgement in the audit process: a test of Kinney's classification. Managerial Auditing Journal, 16(1/2): 4049.

Turley, S., \& Cooper, M. (1991). Auditing in the United Kingdom: A study of development in the audit methodologies of large accounting firms. London: Prentice-Hall.

Umans, T., Broberg, P., Schmidt, M., Nilsson, S., \& Olsson, E. (2016). Feeling well by being together: Study of Swedish auditors. Work, 54(1): 79-86 
Van der Veer, B. (2006). Keynote speech on audit regulation and implementation of the statutory audit directive. FEE Conference on Audit Regulation, October, 2006.

Webb, C., \& Kevern, J. (2001). Focus groups as a research method: A critique of some aspects of their use in nursing research. Journal of Advanced Nursing, 33(6), 798-805.

Weick, K. E. (1989). Theory construction as disciplined imagination. Academy of Management Review, 14, 516-531.

Whittemore, R., Chase, S. K., \& Mandle, C. L. (2001). Validity in qualitative research. Qualitative health research, 11(4), 522-537.

\footnotetext{
i In this paper we use "structure" and "management by documents" as synonymous concepts.

ii See section 2.3 for a description of the concept.

iii The quotes in this paper have been adjusted to more easily readable texts and then translated into English.

iv The auditor who leads the audit team, who signs the audit, and is the main audit office contact for the audit engagement.
} 